\title{
Household Cooking Practices as Risk Factor for Acute Respiratory Infections among Hospitalized Under-5 Children in Ibadan, Nigeria
}

\author{
Adekunle Gregory Fakunle ${ }^{1 *}$, Johnson Oluwaseun Ogundare ${ }^{1,2}$, \\ Ademola Lukman Adelekan ${ }^{3}$, Temilade Adegoke Bello ${ }^{4}$ \\ ${ }^{I}$ Department of Environmental Health Sciences, Faculty of Public Health, University of Ibadan, Ibadan, Nigeria \\ ${ }^{2}$ Department of Clinical Nursing, University College Hospital, Ibadan, Nigeria \\ ${ }^{3}$ Blue Gate Public Health Promotion Initiative, Ibadan, Nigeria \\ ${ }^{4}$ Climate and Society Programme (CSP), Centre for Sustainable Development, University of Ibadan, Nigeria
}

\begin{abstract}
Background: Several studies have assessed the association between biomass fuel use and respiratory infection morbidity and mortality but very limited studies have investigated the practices involved in the use of these biomass fuels in relation to the acquisition of acute respiratory infections (ARI) among under-five children in Nigeria. This study was therefore designed to assess the association between household cooking practices and ARI among under-five children in Ibadan.

Methods: A hospital based case-control study was undertaken. Two hundred and twenty (220) under-5 children with ARI (cases) and 220 without ARI (controls) were selected consecutively from children visiting OniMemorial Children Hospital and University College Hospital, Ibadan. A semi-structured questionnaire was administered to 220 mothers of recruited cases and controls to elicit vital information on household cooking practices and other factors that predispose children under-five to ARIs. Sixty-six consented cases and controls each were followed-up for household survey using an observational checklist. Data were analysed using descriptive statistics, Chi-square and logistic regression at $p<0.05$.

8Results: The mean age of mothers of cases was $28.7 \pm 5.6$ years as compared to $30.3 \pm 6.6$ years for mothers of controls. Mean ages of cases and controls were $20.4 \pm 14.7$ and $20.3 \pm 15.0$ months respectively. More cases than controls belong to households with a household size greater than 5 persons $(O R=2.5 ; 95 \% C I=1.6-$ 3.6). A large proportion of household of cases than controls engage in inadequate cooking practices $(O R=2.4$; 95\% CI = 1.6-3.5). Under-five children carried on the back while cooking were found to be thrice more likely to develop ARIs than children whose mothers do not carry while cooking. The odds ratios of acute respiratory infection were 8.2 (95\% CI: 3.7-18.0) and 3.0 (95\% CI: 1.3-6.9) in households using firewood and charcoal for cooking respectively. Children whose household cook in the same room where the child sleeps were found to have a 3-fold greater risk of ARIs than children belonging to household that has its separate kitchen.

Conclusions: Inadequate household cooking practices play an important role in the acquisition of acute respiratory infections among under-five children. Increase awareness on the importance of good cooking practices with regard to prevention and control of ARIs among under-5 children is therefore recommended.
\end{abstract}

Keywords: Household cooking practice, Acute respiratory infections, Under-5 children

\section{Introduction}

Acute respiratory infection (ARI) has been reported to be responsible for about 845,000 deaths among under-five children in 2010 [1]. In sub-Saharan Africa, the situation is especially grave with about 378, 000 deaths from ARI occurring in this region alone [2]. Factors contributing to the high burden attributable to ARIs among under-five children include malnutrition, exposure to household air pollution (HAP) from solid fuel use and inadequate healthcare systems that limit access to appropriate treatment. In Sub-Saharan Africa, 77\% of households depend on solid fuels as major sources of energy for heating and cooking in the year 2010 [3], and interestingly, this figure has remained largely unchanged since the 1980s [3-4]. The process of burning solid fuels on open fires or simple stoves produces high concentrations of pollutants, including particulate matter (PM), carbon monoxide (CO), nitrogen oxides $\left(\mathrm{NO}_{2}\right)$ and major carcinogens including polyaromatic hydrocarbons and benzene [5]. Studies among under-five children have reported a two-fold increase in the odds of suffering from ARI from exposure to HAP [6]. In addition, HAP has been reported as a known risk factor for chronic obstructive pulmonary disease, cataract, cardiovascular disease and cancer among adults, and was responsible for 3.5 million global deaths in the year 2010 [7]. In Sub-Saharan Africa, HAP was considered the second most important risk factor for ARI among under-five children after malnutrition [7]. 
In Nigeria, despite the numerous natural resources for hydro-electric power, report by Maduka [8] indicated that Nigeria relied so much on traditional energy sources such as firewood (fuelwood), bagasse and crop residues for her daily energy needs. Maduka [8] also reported that an estimated 55\% of Nigeria's primary energy requirement for heating and cooking in the home comes from firewood, biomass, charcoal and animal waste. Several studies have investigated the association between biomass fuel use and respiratory infection morbidity and mortality [9]. Studies conducted in Zimbabwe and India used cooking fuel type to group children into different categories of exposure [10-11]. To the best of our knowledge, information on practices involved in the use of these biomass fuels in relation to the acquisition of acute respiratory infections among under-five children in Nigeria remains unknown. This study was therefore designed to assess the association of household cooking practices and ARI among under-five children in Ibadan.

\subsection{Description of the study Area}

\section{Methodology}

The study was carried out in Ibadan located in South-west Nigeria. Its population is estimated to be, about 2,550,593 according to 2006 census and is reputed to be the largest indigenous city in Africa, south of the Sahara. The principal inhabitants of the city are the Yorubas. The city is situated at an altitude ranging from 152 to 213 metres above sea level in a tropical rain forest. The wet season of the year runs from June through October (though occasional showers occur as early as March). In the wet season, temperature ranges from $21^{\circ} \mathrm{C}$ to $31^{\circ} \mathrm{C}$, rainfall from $8.4 \mathrm{~cm}$ to $18.8 \mathrm{~cm}$ and humidity from $54 \%$ to $77 \%$. In the dry season temperature ranges from $20^{\circ} \mathrm{C}$ to $31^{\circ} \mathrm{C}$, rainfall from $1 \mathrm{~cm}$ to $4.4 \mathrm{~cm}$ and humidity from $43 \%$ to $83 \%$.

\subsection{Subject recruitment and community follow-up}

A hospital-based case-control study design was undertaken. Two hundred and twenty children underfive years of age admitted with ARI to the paediatric department of Oni-Memorial Children Hospital and Otunba-Tunwase Emergency Hospital, University of Ibadan (120 beds and 260 beds, respectively) from January to April, 2012 were recruited. The WHO criteria was used for case definition of ARI i.e. "presence of cough with fast breathing in more than 60 breath/minute in less than 2 months, $\geq 50$ breaths/ minute for children aged 2-11 months and > 40 breaths/minute for children aged 12-59 months". Controls were selected from children under-five years old, who were the same age, sex and level of maternal education (illiterate, primary, secondary, or tertiary education) hospitalized in the same ward during the same period for causes other than respiratory infections as well as from those attending immunization clinics. With respect to community assessment, a total of 66 cases and controls each gave consent for household survey. A community-based follow-up of 66 consented cases and controls was therefore carried out using an observational checklist. Children under-five excluded from this study included those with congenital heart disease, asthma, recurrent pneumonia, cystic fibrosis, pulmonary tuberculosis, immunodeficiency, hospital acquired pneumonia, aspiration pneumonia, foreign body inhalation, any chronic illness, children having measles or history of measles in last one month were excluded from the study.

\subsection{Questionnaire Survey and Observation of household cooking practices}

A semi-structured questionnaire was administered to the 220 mothers of recruited cases and controls to elicit vital information on household cooking practices and other factors that predispose children under-five to ARIs.A 32-point scale questions was used to assess cooking practices in households of cases and controls. Household cooking practice was scored by allocating 1 point for positive answers and zero for negative answers. A total score of $0-13$ points or less than or equal to $50^{\text {th }}$ percentile was categorized as "inadequate cooking practice" while scores ranging from 14-32 points or above $50^{\text {th }}$ percentile was categorized as "adequate cooking practice". An observational checklist was used to also assess household cooking practices in houses of 132 consented cases and controls. Some of the characteristics checked for include the type of fuel used in cooking, location of cooking and ventilation using number of windows per room.

\subsection{Statistical analysis}

Descriptive statistics was used to analyse and summarize the data. Analyses were conducted using SPSS software version 15 (IBM SPSS Statistics). Inferential statistics Chi-square $\left(\mathrm{X}^{2}\right)$ was used to test for association between qualitative variables between cases and controls. Odds ratios and their $95 \%$ confidence intervals were also computed.

\subsection{Ethical consideration}

The study was approved by the UI/UCH ethics committee. Verbal, informed consent of the child's mother was obtained for both cases and controls. 


\section{Results}

\subsection{Respondents' socio-demographic characteristics}

Table 1 highlights the basic characteristics of mothers and their children that were recruited into the study. The mean age of mothers of cases was $28.77 \pm 5.55$ years as compared to $30.34 \pm 6.56$ years for mothers of controls. Majority of mothers for cases 214 (97.3\%) and controls 209 (95\%) were below 40 years of age. A large proportion of mothers of cases reported a monthly income of $<\$ 20,000$ while mothers of controls reported between $\$ 20,000$ and $\$ 50,000$ per month. The mean age of children under-five among cases and controls was $20.41 \pm 14.7$ months and $20.3 \pm 15.0$ months respectively. Out of 220 cases and controls each, 122 $(55.5 \%)$ were males and $98(44.5 \%)$ were females in each group. The majority, $142(65.0 \%)$ were between the age of 12 - <60 months; $59(26.8 \%)$ were between 2 -12 months of age; and $19(8.6 \%)$ were between $12-<60$ months of age.

Table 1: Respondents' socio-demographic characteristics

\begin{tabular}{|c|c|c|}
\hline Child's Characteristics & $\begin{array}{l}\text { Cases } \\
\text { n }(\%)\end{array}$ & $\begin{array}{c}\text { Controls } \\
\text { n }(\%)\end{array}$ \\
\hline $\begin{array}{c}\text { Mothers' Age: (Years) } \\
\text { 20 years and Below } \\
21-25 \\
36-30 \\
31-35 \\
36-40 \\
41 \text { years and above }\end{array}$ & $\begin{array}{c}16(7.3 \%) \\
45(20.5 \%) \\
90(40.9 \%) \\
44(20.0 \%) \\
19(8.6 \%) \\
6(2.7 \%)\end{array}$ & $\begin{array}{c}11(5.0 \%) \\
47(21.4 \%) \\
64(29.1 \%) \\
55(25.0 \%) \\
32(14.5 \%) \\
11(5.0 \%)\end{array}$ \\
\hline $\begin{array}{c}\text { Mother's Educational Status } \\
\text { illiterate } \\
\text { Primary } \\
\text { Secondary } \\
\text { Tertiary }\end{array}$ & $\begin{array}{l}4(1.8 \%) \\
57(25.9 \%) \\
115(52.3 \%) \\
44(20.0 \%)\end{array}$ & $\begin{array}{l}3(1.4 \%) \\
58(26.4 \%) \\
115(52.3 \%) \\
44(20.0 \%)\end{array}$ \\
\hline $\begin{array}{c}\text { Family Income } \\
<20000 \\
20000-50000 \\
>50000\end{array}$ & $\begin{array}{c}131(59.5 \%) \\
86(39.1 \%) \\
3(1.4 \%)\end{array}$ & $\begin{array}{c}81(36.8 \%) \\
129(58.6 \%) \\
10(4.5 \%)\end{array}$ \\
\hline $\begin{array}{c}\text { Age: months } \\
0-<2 \\
2-<12 \\
12-<60 \\
\text { Mean } \pm \text { SD }\end{array}$ & $\begin{array}{c}18(8.2 \%) \\
59(26.8 \%) \\
142(65.0 \%) \\
20.4 \pm 14.7\end{array}$ & $\begin{array}{c}19(8.6 \%) \\
59(26.8 \%) \\
143(64.5 \%) \\
20.3 \pm 15.0\end{array}$ \\
\hline $\begin{array}{c}\text { Sex of the Child } \\
\text { Male } \\
\text { Female }\end{array}$ & $\begin{array}{l}122(55.5 \%) \\
98(44.5 \%)\end{array}$ & $\begin{array}{c}122(55.5 \%) \\
98(44.5 \%)\end{array}$ \\
\hline $\begin{array}{c}\text { Birth Order } \\
\mathbf{1}^{\text {st }} \\
2^{\text {nd }} \\
3^{\text {rd }} \\
4^{\text {th }} \\
5^{\text {th }} \\
6^{\text {th }}\end{array}$ & $\begin{array}{c}55(25.0 \%) \\
80(36.4 \%) \\
51(23.1 \%) \\
22(10.0 \%) \\
11(5.0 \%) \\
1(0.5 \%)\end{array}$ & $\begin{array}{c}55(25.0 \%) \\
80(36.4 \%) \\
50(22.1 \%) \\
22(10.0 \%) \\
12(6.0 \%) \\
1(0.5 \%)\end{array}$ \\
\hline
\end{tabular}

\subsection{Household characteristics}

The characteristics of household of cases and controls are presented in table 2. More cases than controls reside in houses with household size greater than 5 persons ( $\mathrm{OR}=2.5 ; 95 \% \mathrm{CI}=1.6-3.6)$. In terms of the number of rooms which cases and controls resides, more cases than controls reside in a single room $(\mathrm{OR}=$ 1.7 ; $\mathrm{CI}=1.1-2.5$ ). A large proportion of houses of cases than controls has no separate kitchen for cooking purposes $(\mathrm{OR}=2.0 ; 95 \% \mathrm{CI}=1.3-3.0)$. Similarly, a large proportion of cases than controls plays nearby cooking area $(\mathrm{OR}=2.6 ; 95 \% \mathrm{CI}=1.6-4.3)$. Under-five children whose mother carries on the back while cooking were found to be thrice more likely to develop ARIs than children whose mothers do not carry while cooking. More houses among cases than controls have less than 2 windows $(\mathrm{OR}=3.2$; 95\% C.1 = 2.0-4.7) (Table 2). 
Household Cooking Practices As Risk Factor for Acute Respiratory Infections among Hospitalized ..

Table 2: Univariate Analysis of housing factors that contributes to ARI among under-five

\begin{tabular}{|c|c|c|c|}
\hline Variable & $\begin{array}{c}\text { Cases } \\
(\mathbf{n}=\mathbf{2 2 0})\end{array}$ & $\begin{array}{l}\begin{array}{l}\text { Control } \\
(\mathbf{n}=\mathbf{2 2 0})\end{array} \\
\end{array}$ & $\begin{array}{c}\text { Unadjusted OR } \\
(95 \% \mathrm{CI})\end{array}$ \\
\hline Household size & $\begin{array}{c}155(70.5 \%) \\
65(29.5 \%)\end{array}$ & $\begin{array}{l}108(49.1 \%) \\
112(50.9 \%)\end{array}$ & $\begin{array}{l}2.5(1.6-3.6) \\
1.0\end{array}$ \\
\hline Number of rooms & $\begin{array}{c}144(65.5 \%) \\
76(34.5 \%)\end{array}$ & $\begin{array}{l}115(52.3 \%) \\
105(47.7 \%)\end{array}$ & $\begin{array}{l}1.0 \\
1.7(1.1-2.5)\end{array}$ \\
\hline $\begin{array}{c}\text { No separate kitchen in the house? } \\
\text { Yes } \\
\text { No }\end{array}$ & $\begin{array}{l}100(45.5 \%) \\
120(54.5 \%)\end{array}$ & $\begin{array}{l}64(29.1 \%) \\
156(70.9 \%)\end{array}$ & $\begin{array}{l}1.0 \\
2.0(1.3-3.0)\end{array}$ \\
\hline $\begin{array}{r}\text { No of windows in the house? } \\
<2 \\
\geq 2\end{array}$ & $\begin{array}{l}106(48.6 \%) \\
112(51.4 \%)\end{array}$ & $\begin{array}{c}51(23.2 \%) \\
169(78.8 \%)\end{array}$ & $\begin{array}{l}3.1(2.0-4.7) \\
1.0\end{array}$ \\
\hline $\begin{array}{c}\text { Does your child play nearby you while cooking? } \\
\text { Yes } \\
\text { No }\end{array}$ & $\begin{array}{c}61(27.7 \%) \\
159(72.3 \%)\end{array}$ & $\begin{array}{l}28(12.7 \%) \\
192(87.3 \%)\end{array}$ & $\begin{array}{l}2.6(1.6-4.3) \\
1.0\end{array}$ \\
\hline 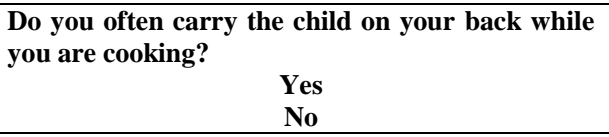 & $\begin{array}{c}66(30.0 \%) \\
154(70.0 \%) \\
\end{array}$ & $\begin{array}{l}26(11.8 \%) \\
194(88.4 \%)\end{array}$ & $\begin{array}{l}3.2(1.9-5.3) \\
1.0\end{array}$ \\
\hline
\end{tabular}

\subsection{Household Cooking Practices}

The cooking practice in houses of cases and controls is presented in table 3 and 4 . A large proportion of household of cases than controls carry out inadequate cooking practices $(\mathrm{OR}=2.4 ; 95 \% \mathrm{CI}=1.6-3.5)$. The unadjusted odds of having suffered from ARI was 8 times higher among children belonging to household that uses firewood for cooking (Table 3). A large proportion of households of cases than controls cook using charcoal $(\mathrm{OR}=3.0 ; 95 \% \mathrm{CI}=1.3-6.9)$. Majority of household of cases than controls cook in the same bedroom where the child sleeps $(\mathrm{OR}=3.5 ; 95 \% \mathrm{CI}=1.3-9.5)$. Children under five belonging to households that cook at the door very close to the room were found to be 10 times more likely to develop ARIs than children whose household does not. The proportion of household of cases that cook in a separate kitchen were found to be less than controls $(\mathrm{OR}=0.06 ; 95 \% \mathrm{CI}=0.01-0.2)$. A logistic regression model found that overcrowding (measured using the number of persons in the household), mother carrying child at the back while cooking, cooking using firewood and charcoal, cooking in the same room where the child sleeps, cooking at the entrance of the room were major independent risk factor for ARIs in under five children (Table 4).

Table 3: Household cooking Practice among cases and controls

\begin{tabular}{|c|c|c|c|}
\hline \multirow{2}{*}{ Practice/Category } & \multicolumn{2}{|c|}{ Household } & \multirow{2}{*}{ p-value } \\
\cline { 2 - 3 } & Cases & $101(45.9 \%)$ & \multirow{2}{*}{0.00} \\
\hline Inadequate & $147(66.8 \%)$ & $119(54.1 \%)$ & \\
\hline Adequate & $73(33.2 \%)$ & \\
\hline
\end{tabular}

Table 4: Univariate Analysis of cooking practices in houses of children under-five

\begin{tabular}{|c|c|c|c|}
\hline Variable & Cases $(n=66)$ & Control $(n=66)$ & Unadjusted OR (95\% CI) \\
\hline $\begin{array}{r}\text { Stove for cooking } \\
\text { Yes } \\
\text { No }\end{array}$ & $\begin{array}{c}66(100.0 \%) \\
0(0.0 \%)\end{array}$ & $\begin{array}{c}66(100.0 \%) \\
0(0.0 \%)\end{array}$ & $x_{0}$ \\
\hline $\begin{array}{c}\text { Firewood for cooking } \\
\text { Yes } \\
\text { No } \\
\end{array}$ & $\begin{array}{l}44(66.7 \%) \\
22(33.3 \%)\end{array}$ & $\begin{array}{l}13(19.7 \%) \\
53(80.3 \%)\end{array}$ & $\begin{array}{l}8.2(3.7-18.0) \\
1.0\end{array}$ \\
\hline $\begin{array}{c}\text { Charcoal for cooking } \\
\text { Yes } \\
\text { No } \\
\end{array}$ & $\begin{array}{l}23(34.8 \%) \\
43(65.2 \%) \\
\end{array}$ & $\begin{array}{l}10(15.2 \%) \\
56(84.8 \%)\end{array}$ & $\begin{array}{l}3.0(1.3-6.9) \\
1.0\end{array}$ \\
\hline $\begin{array}{r}\text { Gas for cooking } \\
\text { Yes } \\
\text { No } \\
\end{array}$ & $\begin{array}{c}5(7.6 \%) \\
61(92.4 \%) \\
\end{array}$ & $\begin{array}{l}12(18.2 \%) \\
54(81.8 \%)\end{array}$ & $0.4(0.1-1.1)$ \\
\hline $\begin{array}{c}\text { Electricity for cooking } \\
\text { Yes } \\
\text { No } \\
\end{array}$ & $\begin{array}{l}32(48.5 \%) \\
34(51.5 \%) \\
\end{array}$ & $\begin{array}{l}39(59.1 \%) \\
27(40.9 \%)\end{array}$ & $0.7(0.3-1.3)$ \\
\hline $\begin{array}{c}\text { Cooking done in the Bedroom } \\
\text { Yes } \\
\text { No } \\
\end{array}$ & $\begin{array}{l}17(25.8 \%) \\
49(74.2 \%)\end{array}$ & $\begin{array}{c}6(9.1 \%) \\
60(90.9 \%)\end{array}$ & $\begin{array}{l}3.5(1.3-9.5) \\
1.0\end{array}$ \\
\hline $\begin{array}{l}\text { Cooking done very close to the } \\
\text { door } \\
\qquad \begin{array}{l}\text { Yes } \\
\text { No }\end{array}\end{array}$ & $\begin{array}{l}34(51.5 \%) \\
32(48.5 \%)\end{array}$ & $\begin{array}{c}6(9.1 \%) \\
60(90.9 \%)\end{array}$ & $\begin{array}{l}10.3(4.0-27.9) \\
1.0\end{array}$ \\
\hline
\end{tabular}


Household Cooking Practices As Risk Factor for Acute Respiratory Infections among Hospitalized ..

\begin{tabular}{|c|c|c|l|}
\hline $\begin{array}{c}\text { Cooking done Outside } \\
\text { Yes }\end{array}$ & $\begin{array}{l}34(51.5 \%) \\
\text { No }\end{array}$ & $\begin{array}{c}9(13.6 \%) \\
57(86.4 \%)\end{array}$ & $6.7(2.9-15.8)$ \\
1.0
\end{tabular}

Table 5: Risk factors for ARIs among under-five children using multivariate logistic regression model

\begin{tabular}{|l|l|}
\hline Co-variate & OR $(\mathbf{9 5 \%} \mathbf{C I})$ \\
\hline$\geq 5$ persons in household & $2.3(1.5-3.4)$ \\
\hline Inhabiting < 2 rooms & $1.5(1.1-2.3)$ \\
\hline Mother carrying child at the back while cooking & $3.2(1.7-5.5)$ \\
\hline Cooking using firewood & $8.2(3.8-18.3)$ \\
\hline Cooking using charcoal & $3.0(1.1-6.5)$ \\
\hline Cooking in the same bedroom & $3.5(1.3-9.5)$ \\
\hline Cooking at the door & $10.1(4.0-26.9)$ \\
\hline
\end{tabular}

\section{Discussions}

This study set out to investigate the relationship between household cooking practices and ARI among under-five children. Cooking practices, overcrowding, the use of firewood and charcoal for cooking, cooking done inside the same room where the child sleeps and cooking done at the entrance of the room were significant risk factors for ARI. This study found that a large proportion of household of cases than controls had inadequate cooking practices. This corroborates the report of Buchner and Rehfuess [12] who found indoor cooking practices as a major risk factor for ALRIs. The high level of inadequate cooking practices among household of cases resulted from individual responses which included the opinion of been more comfortable cooking with kerosene stove very close to the room to ensure safety of the food. In addition, majority of cases were of the opinion that cooking can be done inside the room to avoid stress. The high level of overcrowding recorded in our study was as a result of a large number of households of cases and controls living in buildings with separate rooms. Although, this can be attributed to the low monthly income. According to Toivola et al., [13], overcrowding through activities such as talking, sneezing and cleaning could contribute to increased levels of particulate matter which could exacerbate respiratory responses. This study found that more than half $(66.7 \%)$ of cases and far less than half $(19.7 \%)$ of controls used firewood for cooking (i.e. as a substitute for kerosene stove) owing to the instability and unreliability of electricity supply in the country. This is similar to an Indian study which found that $93 \%$ of under-five children with ALRI belonged to households that used a biomass fuel such as firewood for cooking and $14.4 \%$ belonged to households with no separate kitchen [14]. A similar study carried out by Sikolia et al., reported that about $71 \%$ of children with ARIs lived in households that used firewood for cooking $(\mathrm{RR}=1.42)$ [15]. In our study, children carried by mothers or guardian while cooking were 3 times more likely than the controls to have ARIs. The process of burning wood in simple stoves with incomplete combustion emit a large amount of toxins that adversely affect specific and non-specific local defenses of the respiratory tract which result in respiratory illnesses [16]. The practice of carry young children or keeping them nearby cooking areas by mothers or guardians is common in Nigeria. As a result, the child becomes more proximal to cooking stoves/exhaust and they became exposed to the emissions. An increased risk of ALRI associated with the child being carried on the mothers back has been noted in other studies [17-18]. In a case-control study, selection bias and recall bias are especially likely. Selection bias was minimized in this study because cases and controls were recruited from the same population, but there might be some bias in that cases were hospitalized under-5 children and controls were in- and outpatients. Recall bias was minimized by asking mothers specific questions via the questionnaire regarding the family and social environment. A limitation of this study was the inability to make an accurate diagnosis of the respiratory infections. In addition, it is possible that controls shared some risk factors with cases which were hidden because of the study design employed. Nevertheless, to the best of our knowledge, the findings of this study are a basis for an in-depth search for risk factors for ARIs using a more accurate design. Inadequate household cooking practices therefore plays an important role in the acquisition of acute respiratory infections among under-five children. Cases were significantly more exposed than controls to factors such as use of firewood for cooking, cooking in the same room where the child sleeps, cooking at the entrance to the room where the child sleeps, overcrowding and inadequate ventilation which might have contributed to their increased vulnerability to respiratory infections.

\section{References}

[1]. Lozano R, Naghavi M, Foreman K, Lim S, Shibuya K, Aboyans V. (2012) Global and regional mortality from 235 causes of death for 20 age groups in 1990 and 2010: a systematic analysis for the Global Burden of Disease Study 2010. Lancet, 380(9859):2095128 .

[2]. Institute for Health Metrics and Evaluation, Seattle, WA, University of Washington, (2013). GBD Heatmap. Available: http://vizhub.healthdata.org/irank/heat.php. Accessed 3 September 2014. 
[3]. Bonjour S., Adair-Rohani H., Wolf J., Bruce N.G., Mehta. (2013). Solid fuel use for household cooking: country and regional estimates for 1980-2010. Environ Health Perspect, 121(7):784-90.

[4]. Rehfuess E.A., Mehta S., Prüss-Üstün A. (2006). Assessing household solid fuel use - multiple implications for the millennium development goals. Environmental Health Perspectives, 114(3):373-378.

[5]. Bruce N., Perez-Padilla R., Albalak R. (2000). Indoor air pollution in developing countries: A major environmental and public health challenge. Bull World Health Organ, 78(9):1078-92.

[6]. Dherani M., Pope D., Mascarenhas M., Smith K.R., Weber M., Bruce N. (2008). Indoor air pollution from unprocessed solid fuel use and pneumonia risk in children aged under five years: a systematic review and meta-analysis. Bull World Health Organ, 86(5):390-8C.

[7]. Lim S.S., Vos T., Flaxman A.D., Danaei G., Shibuya K., Adair-Rohani H. (2012). A comparative risk assessment of burden of disease and injury attributable to 67 risk factors and risk factor clusters in 21 regions, 1990-2010: a systematic analysis for the Global Burden of Disease Study 2010. Lancet, 380(9859):2224-60.

[8]. Maduka, J.O. (2011). Popularizing the use of Liquefied Petroleum Gas (LPG) as a substitute for fuel wood among women in Nigeria. Proceedings of the 3rd International Conference of the African Renewable Energy Alliance on Renewable Energy and Gender, June 29-July 1, 2011, Abuja, Nigeria

[9]. Ezzati M., Kammen D.M. (2001). Indoor air pollution from biomass combustion and acute respiratory infections in Kenya: an exposure-response study. The Lacent.;358:619-624.

[10]. Mishra M. (2003). Indoor air pollution from biomass combustion and acute respiratory illness in preschool age children in Zimbabwe. International Journal of Epidemiology.;32:847-853

[11]. Mishra M., Smith K. R., Retherford R.D. (2005). Effect of cooking smoke and environmental tobacco smoke on acute respiratory infections in young Indian children. Population and Environment.;26(5):375-396.

[12]. Buchner H., Rehfuess E. A. (2015) Cooking and Season as Risk Factors for Acute Lower Respiratory Infections in African Children: A Cross-Sectional Multi-Country Analysis. PLoS ONE 10(6): e0128933.

[13]. Toivola M., Alm S., Reponen T., Kolari S., Nevalainen A. (2002). Personal exposures and microenvironmental concentrations of particles and bioaerosols. J Environ Monit;4:166-74.

[14]. Broor S., Pandey R.M., Ghosh M., Maitreyi R.S., Lodha R., Singhal T. (2001). Risk factors for severe acute lower respiratory tract infections in under-5 children. Indian Pediatr.;38:1361-7.

[15]. Sikolia D.N., Nwololo K., Cherop H., Hussein T., Juma M., Kurui A. (2002). The prevalence of acute respiratory infections and the associated risk factors: a study of children under-5 years of age in Kibera Lindi Village, Nairobi, Kenya. J Int Public Health.;511:67-72.

[16]. Smith K.R., Bruce N., Balakrishnan K., Adair-Rohani H., Balmes J., Chafe Z., HAP CRA Risk Expert Group. (2014). Millions dead: how do we know and what does it mean? Methods used in the Comparative Risk Assessment of Household Air Pollution. Annual Review of Public Health, 35:185-206.

[17]. Kilabuko, J. H., Nakai, S. (2007), "Effects of Cooking Fuels on Acute Respiratory Infections in Children in Tanzania", International Journal of Environmental Research and Public Health, 4(4), 283-288.

[18]. Habtamu S., Araya A.,Abera K. (2014). Association of biomass fuel use with acute respiratory infections among under- five children in a slum urban of Addis Ababa, Ethiopia BMC Public Health. 2014; 14: 1122. 